\title{
CORRIGENDA
}

\section{Highly effective combination of LSD1 (KDM1A) antagonist and pan-histone deacetylase inhibitor against human AML cells}

W Fiskus, S Sharma, B Shah, BP Portier, SGT Devaraj, K Liu, SP lyer, D Bearss and KN Bhalla

Leukemia (2017) 31, 1658; doi:10.1038/leu.2017.77; published online 21 March 2017

Correction to: Leukemia (2014) 28, 2155-2164; doi:10.1038/ leu.2014.119; published online 25 April 2014

Following the publication of this article, the authors noted that the loading control ( $\beta$-actin) for the primary AML cells data presented in Figure $7 \mathrm{~b}$ was incorrect. The correct western blot for the loading control ( $\beta$-actin) has been added to Figure $7 \mathrm{~b}$. This correction

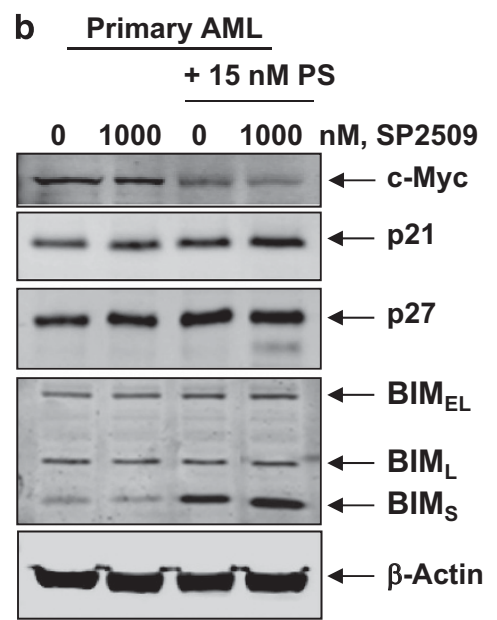

Figure 7. Treatment with SP2509 and/or PS significantly enhances PS-mediated loss of viability of CD34+ primary AML cells and improves the survival of mice bearing AML xenografts and primagrafts. (b) Primary AML cells were treated with SP2509 and/or PS as indicated for 24 hours. Total cell lysates were prepared and immunoblot analyses were conducted for the expression levels of c-Myc, p21, p27, BIM, and $\beta$-actin in the lysates. neither changes the interpretation of the data nor does it alter the overall conclusions of the study. The corrected Figure $7 \mathrm{~b}$ appears below: 